\title{
Modification of the antibiotic olivomycin I at the 2 '-keto group of the side chain. Novel derivatives, antitumor and topoisomerase I-poisoning activity
}

\author{
Anna N Tevyashova ${ }^{1}$, Eugenia N Zbarsky ${ }^{1}$, Jan Balzarini ${ }^{2}$, Alexander A Shtil ${ }^{3}$, Lyubov G Dezhenkova ${ }^{1}$, \\ Vladimir M Bukhman ${ }^{1}$, Victor B Zbarsky ${ }^{1}$ and Maria N Preobrazhenskaya ${ }^{1}$ \\ A novel way of chemical modification of the antibiotic olivomycin I at the 2'-keto group of the side chain of the aglycone \\ moiety was developed. Reaction of olivomycin I with the carboxymethoxylamine hemihydrochloride gave the key intermediate, \\ 2'-carboxymethoxime-olivomycin I, which was further reacted with different amines in the presence of benzotriazol-1-yl-oxy- \\ trispyrrolidinophosphonium hexafluorophosphate to give the corresponding amides. The antiproliferative and topoisomerase I \\ (Topo-I)-poisoning activities of the novel derivatives were examined. One of the novel derivatives showed a marked inhibitory \\ activity against Topo-I, a pronounced antitumor activity in in vivo experiments on mice bearing leukemia P-388 and lower \\ toxic side effects compared with the parent olivomycin I.
}

The Journal of Antibiotics (2009) 62, 37-41; doi:10.1038/ja.2008.7; published online 9 January 2009

Keywords: antitumor activity; aureolic acid antitumor antibiotics; olivomycin I; topoisomerase I

\section{INTRODUCTION}

The aureolic acid family of antitumor antibiotics includes a group of clinically active agents such as olivomycin I (olivomycin A), mithramycin, and also chromomycin $\mathrm{A}_{3}$ and durhamycin. ${ }^{1}$ The antibiotics of the aureolic acid family interact with the DNA minor groove in highGC-content regions in a nonintercalative way and with the requirement for $\mathrm{Mg}^{2+}$ ions. ${ }^{2}$

The antitumor antibiotic olivomycin I was discovered at the Gause Institute of New Antibiotics, Moscow. ${ }^{3}$ Comparative study of the antitumor action of olivomycin $\mathrm{I}$ and chromomycin $\mathrm{A}_{3}$ in in vivo experiments on murine lymphosarcoma LY01 revealed that the chemotherapeutic index $\left(\mathrm{LD}_{50} / \mathrm{DIT}_{50}\right)$ of olivomycin $\mathrm{I}$ is more favorable (2.35) than that of chromomycin $\mathrm{A}_{3}(0.99) .{ }^{4} \mathrm{~A}$ similar study on the inhibitory effect of olivomycin $\mathrm{I}$, chromomycin $\mathrm{A}_{3}$ and mithramycin against transplantable murine leukemia La showed that a similar antitumor effect (an increase in the lifespan of mice by $25 \%$ ) can be achieved at lower doses of olivomycin I than those for the other aureolic acid antibiotics studied. ${ }^{4}$ Clinical investigations of mithramycin and olivomycin I showed that these antibiotics give favorable results in treatment of testicular tumors. It was shown that these antibiotics exhibit side effects such as gastrointestinal, hepatic, renal and bone marrow toxicities. ${ }^{5}$ The major clinically limiting toxicity of mithramycin was a hemorrhagic diathesis associated with a precipitous thrombocytopenia. It is of considerable interest that hemorrhagic diathesis was not observed after administration of olivomycin I. ${ }^{4}$
As olivomycin I possesses the best chemotherapeutic index among the aureolic acid antibiotics, it can be considered as the best scaffold for the development of novel semisynthetic aureolic acid analogs with increased therapeutic indices and lower toxicity compared with the parent antibiotic.

Here we describe chemical modifications of olivomycin I at the 2 '-keto group of the side chain of the aglycone moiety. The antiproliferative and topoisomerase I (Topo-I)-poisoning activities of the novel derivatives (2-7) were tested. One of the novel derivatives showed pronounced antitumor activity in in vivo experiments on mice bearing lymphocyte leukemia P-388, together with lower toxicity to animals compared with the parent olivomycin I.

\section{RESULTS}

Chemistry

We developed a novel method of chemical modification of olivomycin I (1) based on the introduction of a carboxyl group into the molecule of the antibiotic. Reaction of olivomycin I (1) with carboxymethoxylamine gave the key intermediate, $2^{\prime}$-carboxymethoxime-olivomycin I (2) (Scheme 1), which was further reacted with different amines in the presence of PyBOP to give the corresponding amides 3-7. The resulting compounds were purified by column chromatography on silica gel.

TLC and HPLC analyses showed that compounds 2-7 were homogeneous. ${ }^{1} \mathrm{H}$ - and ${ }^{13} \mathrm{C}-\mathrm{NMR}$ investigations of 2 identified all

${ }^{1}$ Laboratory of Chemical Transformation of Antibiotics, Gause Institute of New Antibiotics Russian Academy of Medical Sciences, Moscow, Russia; ${ }^{2}$ Rega Institute for Medical Research, Leuven, Belgium and ${ }^{3}$ Research Institute of Carcinogenesis, Blokhin Cancer Center Russian Academy of Medical Sciences, Moscow, Russia 


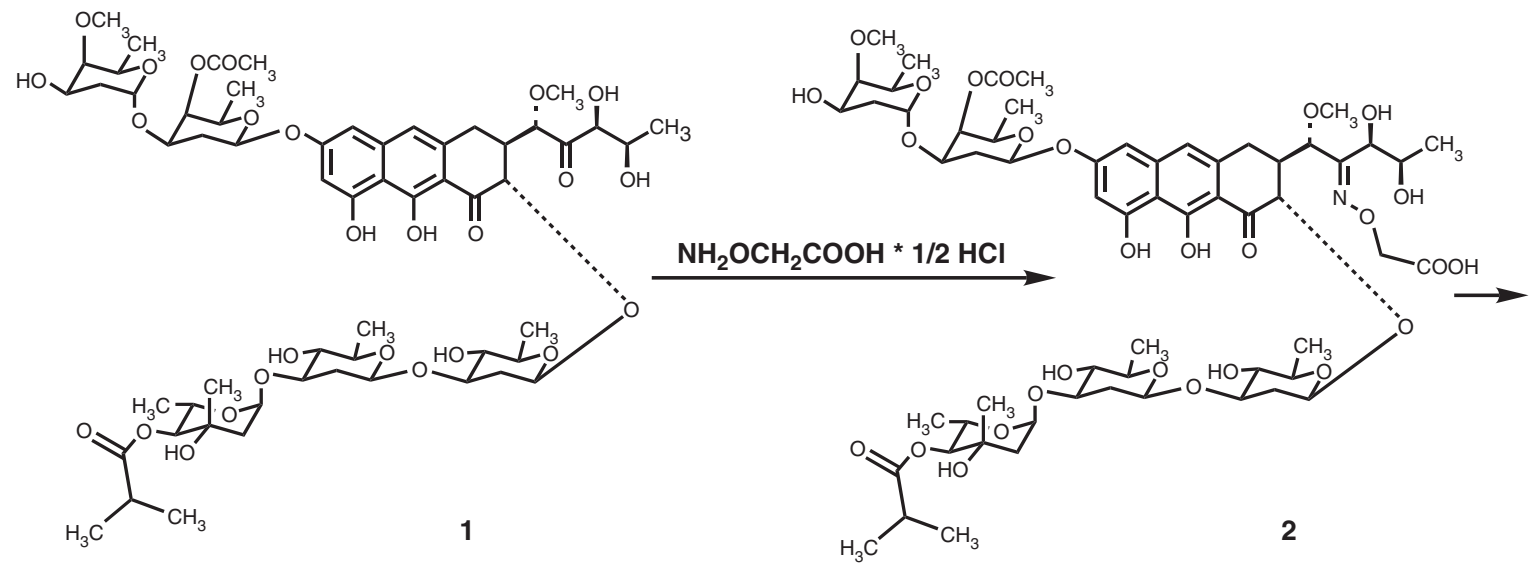<smiles>CCC(C)(C)OC(=O)C(C)C</smiles>

$3 \mathrm{R}=\mathrm{H}$ $4 \mathrm{R}=\mathrm{CH}_{2} \mathrm{CH}_{2} \mathrm{OH}$

$5 \mathrm{R}=$<smiles>CC1C2CC3CC(C2)CC1C3</smiles>

$6 \mathrm{R}=$<smiles>CC(C)(C)C</smiles>

$7 \mathrm{R}=$<smiles>CC(C)(CO)CO</smiles>

Scheme 1

the signals of hydrogen and carbon atoms in aglycone and carbohydrate moieties. The structures of all new derivatives were supported by MS data and by ${ }^{1} \mathrm{H}-\mathrm{NMR}$ spectra (Scheme 1 ).

\section{Biological testing}

The cytotoxicity of the compounds in comparison with the parent olivomycin I was tested. Cells were incubated with drugs for $48-72 \mathrm{~h}$ to ensure the completion of late events in cell death. Table 1 shows the comparative potencies of these compounds against the wild-type murine leukemia L1210 cells, the human leukemia cell line K562 and the human malignant T-lymphocyte Molt4/C8 and CEM cells.

All novel derivatives (2-7) caused cell death at higher concentrations than olivomycin I. Remarkably, amides with the bulky hydrophobic substituents (adamantyl- 5; tert-butyl-, 6) showed antiproliferative activity that was at an $\mathrm{IC}_{50}$ of only one order of magnitude higher (for L1210: 0.19 and $0.20 \mu \mathrm{M}$, correspondingly) than that of olivomycin $\mathrm{I}$, but at a markedly lower $\mathrm{IC}_{50}$ than that of 2 '-carboxymethoxime-olivomycin I (2) or the amides with small or hydrophilic substituents 3, 4 and 7 ( $\mathrm{IC}_{50}$ for L1210: 6.5-20 $\mu \mathrm{M}$ ).

To identify tentative intracellular targets important for cytotoxicity of olivomycin I and its novel derivatives (2-7), we tested these compounds for their ability to modulate Topo-I activity in vitro. Olivomycin I (1) and all novel derivatives (2-7) were potent Topo-I inhibitors at all concentrations investigated $(0.5-20 \mu \mathrm{M})$ (data not shown). Figure 1 shows the results of electrophoretic analysis of the
Table 1 Toxicity of olivomycin I (1) and its derivatives (2-7) against murine leukemia L1210 and human erythroleukemia K562 cells, and human malignant T-lymphocyte Molt4/C8 and CEM cells

\begin{tabular}{lcccc}
\hline & \multicolumn{4}{c}{$C_{50^{\mathrm{a}}}(\mu \mathrm{M})$} \\
\cline { 2 - 5 } Compound & $K 562$ & $L 1210$ & Molt4/C8 & \multicolumn{1}{c}{$C E M$} \\
\hline Olivomycin I & $0.025 \pm 0.002$ & $0.034 \pm 0.002$ & $0.0040 \pm 0.0004$ & $0.0025 \pm 0.0000$ \\
$(\mathbf{1})$ & & & & \\
$\mathbf{2}$ & $>3.2$ & $6.5 \pm 2.8$ & $1.8 \pm 1.4$ & $2.3 \pm 1.6$ \\
$\mathbf{3}$ & $>3.2$ & $3.6 \pm 3.1$ & $1.0 \pm 0.1$ & $0.82 \pm 0.19$ \\
$\mathbf{4}$ & $>3.2$ & $18 \pm 5$ & $3.7 \pm 0.8$ & $6.4 \pm 0.0$ \\
$\mathbf{5}$ & $\mathrm{ND}$ & $0.19 \pm 0.01$ & $0.026 \pm 0.007$ & $0.018 \pm 0.002$ \\
$\mathbf{6}$ & $0.025 \pm 0.002$ & $0.20 \pm 0.01$ & $0.033 \pm 0.003$ & $0.032 \pm 0.001$ \\
$\mathbf{7}$ & $2.47 \pm 1.8$ & $20 \pm 11$ & $3.1 \pm 2.3$ & $4.5 \pm 1.2$ \\
\hline
\end{tabular}

Abbreviation: ND, not determined.

${ }^{\text {al }} \mathrm{C}_{50}$ - the concentration that caused $50 \%$ growth inhibition after $48 \mathrm{~h}$ (L1210) or $72 \mathrm{~h}$ (other cell lines) of exposure.

relaxation products of the Topo-I-dependent supercoiled DNA relaxation in the absence and presence of the antibiotics olivomycin I and $\mathbf{5 .}$ In the absence of antibiotics (track of Topo-I), the reaction led to a set of topoisomers and the disappearance of the supercoiled form of DNA. This effect was revealed by the presence of residual amounts of rapidly migrating topoisomers. Olivomycin I (1) inhibited Topo-I 


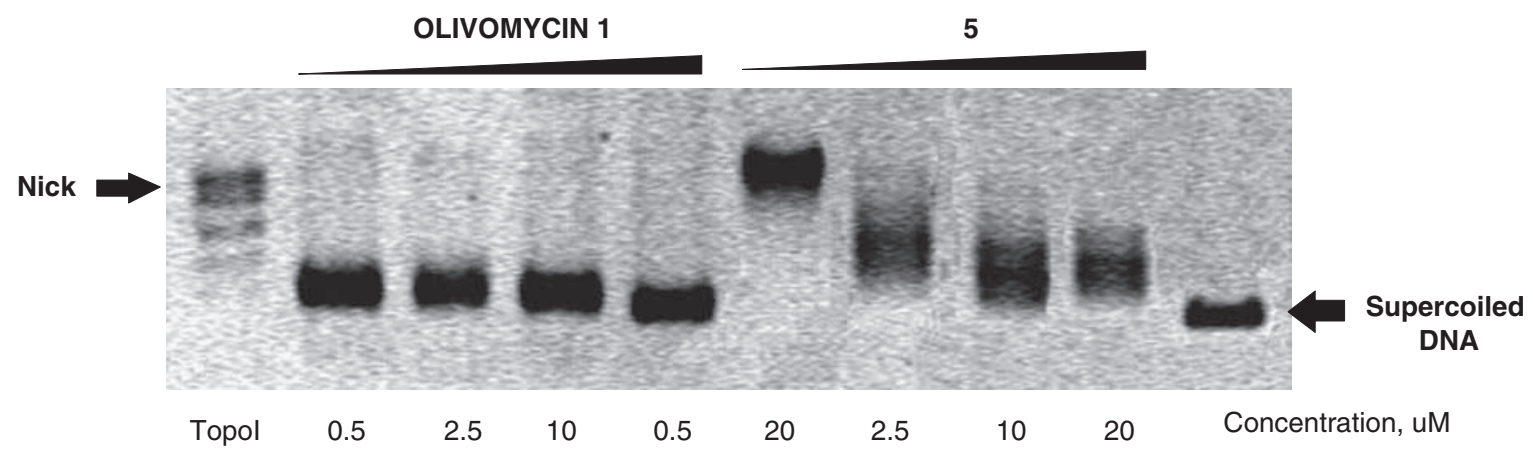

Nick - open circular DNA; Track Topol - enzyme topoisomerase I without compounds; other tracks - topoisomerase I + compounds.

Figure 1 Electrophoretic analysis of the relaxation products of the Topo-I-dependent supercoiled DNA relaxation in the absence and presence of the antibiotics examined. Nick—open circular DNA; Track Topo-I-enzyme topoisomerase I without compounds; other tracks-topoisomerase I-positive compounds.

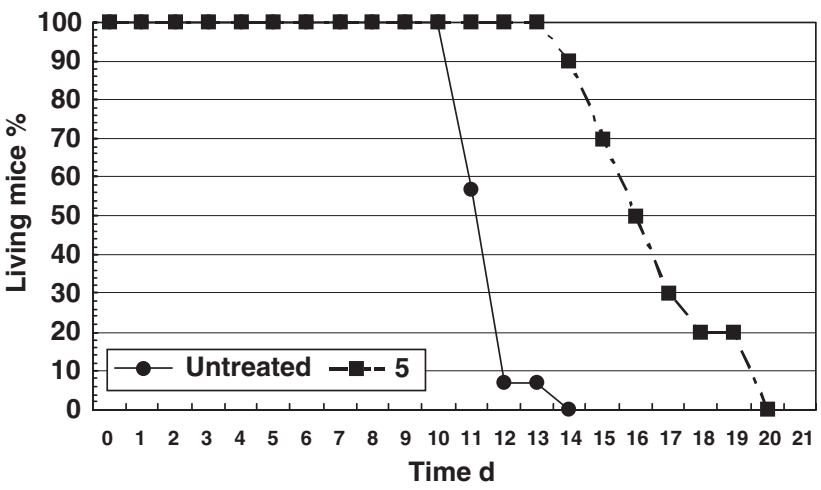

Figure 2 Antitumor activity of olivomycin derivative $\mathbf{5}$ in male mice ((B6D2F1) with leukemia P-388 on quintuple i.p. injection $72 \mathrm{~h}$ after implantation of tumor) at dose of $5 \mathrm{mg} \mathrm{kg}^{-1}$ daily.

activity at all concentrations investigated $(0.5-20 \mu \mathrm{M})$; compound $\mathbf{5}$ was less active but still a potent Topo-I inhibitor-the rapidly migrating topoisomers were observed on the track starting at the compound concentration of $2.5 \mu \mathrm{M}$.

When 5 was i.p. injected to mice with leukemia P-388 $72 \mathrm{~h}$ after i.p. implantation of tumor, $62 \%$ increase of lifespan (ILS) at the dose of $50 \mathrm{mg} \mathrm{kg}^{-1}$ was achieved.

Compound $\mathbf{5}$ did not show any cumulative toxic effects at the quintuple doses of 5 and $10 \mathrm{mg} \mathrm{kg}^{-1}$ (25 and $50 \mathrm{mg} \mathrm{kg}^{-1}$ total dose, respectively), whereas all of the mice that received 1 ( $5 \mathrm{mg} \mathrm{kg}^{-1}$ daily) had drug-related toxic death after the third injection (data no shown). All mice that received daily doses of 5 and $10 \mathrm{mg} \mathrm{kg}^{-1}$ had tumorrelated death. The ILS was $43 \%$ compared with the group of untreated mice (Figure 2). Quintuple injections of 5 at $20 \mathrm{mg} \mathrm{kg}^{-1}$ per dose (100 $\mathrm{mg} \mathrm{kg}^{-1}$ total dose) resulted in drug-related death of $15 \%$ of the mice (data not shown).

\section{DISCUSSION}

In most antitumor antibiotic families, extensive efforts have been made to prepare different semisynthetic derivatives and analogs. However, no systematic efforts have been made for the aureolic acid-type antibiotics. In the past decades, a number of aureolic acid analogs were obtained from genetically engineered mutant producers showing distinct structural changes. ${ }^{5-8}$ This has yielded in some information on the structure-activity relationship of this type of compounds.

It is known that deoxysugars are necessary for stabilizing the complex of the antibiotic with DNA, and that their structures influence the sequence specificity of binding. Earlier, we have shown that olivomycin I in nanomolar concentrations induces apoptosis of human tumor cells and inhibits p53-dependent transcription of the reporter gene, whereas its aglycone olivine has no cytotoxicity and does not block transcription. ${ }^{9}$ Whereas modifications of the carbohydrate and aglycone moieties decreased biological activity significantly, changes in the side chain were more promising. ${ }^{5,8}$

In an effort to find new analogs with improved pharmacological properties, we developed a novel method of chemical modification of the aureolic acid antibiotic olivomycin I on the side chain of the aglycone moiety. The key intermediate, 2 '-carboxymethoxime-olivomycin I (2), contains a carboxyl group that allowed further modifications. A series of amides of $\mathbf{2}$ was thus prepared. Studies of the antiproliferative activity of the novel compounds on different tumor cell lines revealed that the structure of the amine residue greatly influenced the eventual cytotoxicity of the new derivatives. Thus, by varying the amine introduced into the acylation reaction with (2), one can obtain olivomycin I derivatives with different antiproliferative activities. Moreover, for the first time it was shown that olivomycin I and its novel derivatives $(2-7)$ are potent Topo-I poisons. It is known that DNA topoisomerases, which solve topological problems created by the double-helical structure of DNA in essential cellular processes, are the targets of many therapeutic agents. ${ }^{10}$ Known Topo-I inhibitors, particularly camptothecin and its analogs, inhibit Topo-I activity by trapping a reversible Topo-I-DNA cleavable complex. Some undesirable problems (that is, rapid diffusion of the drug from the Topo-I-DNA complex and tumor resistance to these drugs) justify the importance of a search for other types of drugs that act on Topo-I by a different mode of action. ${ }^{11}$ The discovery in this study that olivomycin I and its analogs are effective Topo-I poisons and are endowed with antitumor activity and lesser side effects in mice than the parent drug extends the potential of this class of antibiotics as novel drug candidates for further (pre)clinical investigations. 


\section{MATERIALS AND METHODS}

\section{General experimental procedures}

Olivomycin I was produced at the pilot plant of the Gause Institute of New Antibiotics. Carboxymethoxylamine hemihydrochloride and benzotriazol-1-yloxy-trispyrrolidinophosphonium hexafluorophosphate (PyBOP) were purchased from Acros (Geel, Belgium). All the other reagents and solvents were purchased from Aldrich (St Louis, MO, USA) and Merck (Darmstadt, Germany). Reaction products were purified by column chromatography on Merck silica gel G60 $(0.040-0.063 \mu \mathrm{M})$. Reaction progress, column eluates and all final samples were analyzed by TLC and HPLC. TLC was performed on Merck $\mathrm{G}_{60} \mathrm{~F}_{254}$-precoated plates in the following system (system A): $\mathrm{CHCl}_{3}-\mathrm{MeOH}-$ $\mathrm{HCOOH}, 9: 1: 0.05$. The spots were detected visually and with an ultraviolet lamp at $254 \mathrm{~nm}$. Melting points were determined on Buchi SMP-20 and are uncorrected. HPLC analyses were performed on a Shimadzu HPLC LC 50 instrument equipped with a Diaspher C18 column $(4.0 \times 250 \mathrm{~mm}, 5 \mu \mathrm{k}$; BioChem Mack, Moscow, Russia) and a variable-wavelength ultraviolet detector set at $274 \mathrm{~nm}$ with an injection volume of $10 \mu \mathrm{l}$. Elutions were carried out at a flow rate of $110 \mu \mathrm{min}^{-1}$ using a $0.01-\mathrm{N}_{3} \mathrm{PO}_{4}-\mathrm{MeCN}$ mixture, $\mathrm{pH}$ 2.6, at $20^{\circ} \mathrm{C}$ using a gradient of $\mathrm{MeCN}$ from 40 to $80 \%$. The sample concentration was $0.05-0.2 \mathrm{mg} \mathrm{ml}^{-1}$. ${ }^{1} \mathrm{H}$ - and ${ }^{13} \mathrm{C}$-NMR spectra were recorded on a Varian VXR400 spectrometer at $400 \mathrm{MHz}$ using the DQCOSY method. ${ }^{1} \mathrm{H}$ - and ${ }^{13} \mathrm{C}-\mathrm{NMR}$ spectra were recorded on a Varian VXR-400 NMR spectrometer at $35^{\circ} \mathrm{C}$ and referenced to TMS observing protons at $400 \mathrm{MHz}$ and ${ }^{13} \mathrm{C}$ at $100 \mathrm{MHz}$. Mass spectra determined by electrospray ionization (ESI) were recorded on a Finnigan MAT 900S spectrometer (Brucker, Bremen, Germany) and those determined by matrix-assisted laser desorption/ionization (MALDI) were recorded on Brucker BIFLEX III (Brucker). The data for the predominant monoisotope peak are presented. All solutions were dried over sodium sulfate and evaporated at reduced pressure on a Buchi rotary evaporator at a temperature below $35^{\circ} \mathrm{C}$.

${ }^{1} \mathrm{H}$ - and ${ }^{13} \mathrm{C}-\mathrm{NMR}$ spectra of olivomycin I $\left(\mathrm{CDCl}_{3}\right.$ and DMSO- $\left.\mathrm{d}_{6}\right)$ fully corresponded to the ${ }^{1} \mathrm{H}$ - and ${ }^{13} \mathrm{C}-\mathrm{NMR}$ spectra $\left(\mathrm{CDCl}_{3}\right.$ and DMSO- $\left.\mathrm{d}_{6}\right)$ described in the literature. ${ }^{12,13}$

\section{2'-(Carboxymethoxime)-olivomycin I (2)}

Carboxymethoxylamine hemihydrochloride $(4.5 \mathrm{mg}, 0.42 \mathrm{mmol})$ was added to the solution of olivomycin I $(100 \mathrm{mg}, 0.084 \mathrm{mmol})$ in $\mathrm{MeOH}(3 \mathrm{ml})$. The reaction mixture was kept at $37^{\circ} \mathrm{C}$ for $50 \mathrm{~h}$. It was evaporated and the crude residue was purified by column chromatography on silica gel; elution was carried out with $\mathrm{CHCl}_{3}-\mathrm{MeOH}-\mathrm{HCOOH}$ (9:1:0.05). The resulting fractions were combined and evaporated to a small volume. Addition of petroleum ether gave a precipitate, which was filtered off, washed with petroleum ether and dried in vacuum to yield 2 as an amorphous powder (53 mg, 50\%). Rf 0.42 (system A), HPLC at room temperature (Rt) 12.38 min, m.p. $140-142{ }^{\circ} \mathrm{C}$ (decomposition). MALDI-MS: calculated MW for $\mathrm{C}_{60} \mathrm{H}_{87} \mathrm{NO}_{28}$ 1269.54, observed MW $1292.63(\mathrm{M}+\mathrm{Na})^{+}$.

The ${ }^{1} \mathrm{H}-\mathrm{NMR}$ spectrum (DMSO- $\mathrm{d}_{6}$ ) of 2 corresponded to the ${ }^{1} \mathrm{H}-\mathrm{NMR}$ spectrum of olivomycin $\mathrm{I},{ }^{13}$ except for the presence of the signal at 4.63 p.p.m. $\left(\mathrm{s}, 2 \mathrm{H},-\mathrm{OCH}_{2}\right)$.

The ${ }^{13} \mathrm{C}$-NMR spectrum (DMSO- $\mathrm{d}_{6}$ ) of 2 corresponded to the ${ }^{13} \mathrm{C}$-NMR spectrum (DMSO- $\mathrm{d}_{6}$ ) of olivomycin $\mathrm{I}^{12}$ except for the absence of the signal at 211.81 p.p.m. (2'-carbonyl group), and the presence of signals at 171.203 p.p.m. ( $-\mathrm{COOH}), 158.815$ p.p.m. $(-\mathrm{C}=\mathrm{N}-)$ and 70.45 p.p.m. $\left(-\mathrm{OCH}_{2}\right)$.

\section{2-Adamantylamide of $\mathbf{2}^{\prime}$-(carboxymethoxime)-olivomycin I (5)}

2-Adamantylamine hydrochloride $(14.6 \mathrm{mg}, 0.078 \mathrm{mmol}$ ) was added to the solution of $2^{\prime}$-(carboxymethoxime)-olivomycin I (2) $(50 \mathrm{mg}, 0.039 \mathrm{mmol})$ in $\mathrm{MeOH}(3 \mathrm{ml}) . \mathrm{Et}_{3} \mathrm{~N}$ was added to the reaction mixture to adjust the $\mathrm{pH}$ to 8-8.5 and afterwards PyBOP $(30 \mathrm{mg}, 0.058 \mathrm{mmol})$ was added portion-wise. The reaction mixture was stirred at $22^{\circ} \mathrm{C}$ for $2 \mathrm{~h}$. The reaction mixture was evaporated and the crude residue was purified by column chromatography on silica gel; elution was carried out first with $\mathrm{CHCl}_{3}$ and then with $\mathrm{CHCl}_{3}-$ $\mathrm{MeOH}-\mathrm{HCOOH}$ (9:1:0.05). The fractions with the targeted compound were combined and evaporated to a small volume. Addition of petroleum ether gave a precipitate, which was filtered off, washed with petroleum ether and dried in vacuum to yield $\mathbf{5}$ as an amorphous powder (30 mg, 55\%). Rf 0.27 (system A),
HPLC at Rt 19.46 min, m.p. $155-157^{\circ} \mathrm{C}$ (decomposition). MALDI-MS: calculated MW for $\mathrm{C}_{70} \mathrm{H}_{102} \mathrm{~N}_{2} \mathrm{O}_{27}$ 1402.67, observed MW $1425.47(\mathrm{M}+\mathrm{Na})^{+}$.

The ${ }^{1} \mathrm{H}-\mathrm{NMR}$ spectrum (DMSO- $\mathrm{d}_{6}$ ) of $\mathbf{5}$ corresponded to the ${ }^{1} \mathrm{H}-\mathrm{NMR}$ spectrum of olivomycin $\mathrm{I},{ }^{13}$ except for the presence of signals of adamantyl residue at $1.0-2.43$ p.p.m. (15H), 4.49 p.p.m. (m, 1H) and 4.63 p.p.m. $\left(\mathrm{s}, 2 \mathrm{H},-\mathrm{OCH}_{2}\right)$.

\section{Amide of 2 -(carboxymethoxime)-olivomycin I (3)}

Compound 3 was obtained in the same manner as $\mathbf{5}$, starting from $2(50 \mathrm{mg}$, $0.039 \mathrm{mmol}), \mathrm{NH}_{4} \mathrm{Cl}(6.3 \mathrm{mg}, 0.12 \mathrm{mmol})$ and $\mathrm{PyBOP}(30 \mathrm{mg}, 0.058 \mathrm{mmol})$. Yield $19 \mathrm{mg}$ (38\%). Rf 0.44 (system A), HPLC at Rt 10.15 min, m.p. $162-167^{\circ} \mathrm{C}$ (decomposition). ESI-MS: calculated MW for $\mathrm{C}_{60} \mathrm{H}_{88} \mathrm{~N}_{2} \mathrm{O}_{27}$ 1268.56, observed MW $1291.34(\mathrm{M}+\mathrm{Na})^{+}$.

The ${ }^{1} \mathrm{H}-\mathrm{NMR}$ spectrum (DMSO- $\mathrm{d}_{6}$ ) of 3 corresponded to the ${ }^{1} \mathrm{H}-\mathrm{NMR}$ spectrum of olivomycin $\mathrm{I},{ }^{13}$ except for the presence of the signal at 4.63 p.p.m. $\left(\mathrm{s}, 2 \mathrm{H},-\mathrm{OCH}_{2}\right)$.

\section{Ethanolamide of $2^{\prime}$-(carboxymethoxime)-olivomycin I (4)}

Compound 4 was obtained in the same manner as $\mathbf{5}$, starting from $2(30 \mathrm{mg}$, $0.024 \mathrm{mmol})$, ethanolamine hydrochloride $(6.9 \mathrm{mg}, 0.071 \mathrm{mmol})$ and РyBOP ( $18.4 \mathrm{mg}, 0.035 \mathrm{mmol}$ ). Yield $16 \mathrm{mg}(51 \%)$. Rf 0.51 (system A), HPLC at Rt $9.71 \mathrm{~min}$, m.p. $140-142^{\circ} \mathrm{C}$ (decomposition). ESI-MS: calculated $\mathrm{MW}$ for $\mathrm{C}_{62} \mathrm{H}_{92} \mathrm{~N}_{2} \mathrm{O}_{28}$ 1312.58, observed MW $1313.39(\mathrm{M}+\mathrm{Na})^{+}$.

The ${ }^{1} \mathrm{H}$-NMR spectrum (DMSO- $\mathrm{d}_{6}$ ) of 4 corresponded to the ${ }^{1} \mathrm{H}-\mathrm{NMR}$ spectrum of olivomycin $\mathrm{I}^{13}$ except for the presence of signals at 3.40 3.80 p.p.m. $\left(4 \mathrm{H},-\mathrm{OCH}_{2} \mathrm{CH}_{2} \mathrm{~N}\right)$ and 4.63 p.p.m. (s, $\left.2 \mathrm{H},-\mathrm{OCH}_{2}\right)$.

\section{Tert-butylamide of $2^{\prime}$-(carboxymethoxime)-olivomycin I (6)}

Compound 6 was obtained in the same manner as 5, starting from $2(60 \mathrm{mg}$, $0.047 \mathrm{mmol})$, tert-butylamine hydrochloride $(15.2 \mathrm{mg}, 0.142 \mathrm{mmol})$ and PyBOP (36.8 mg, $0.071 \mathrm{mmol}$ ). Yield $26 \mathrm{mg}$ (42\%). Rf 0.66 (system A), HPLC at Rt 15.26 min, m.p. $145-147^{\circ} \mathrm{C}$ (decomposition). ESI-MS: calculated MW for $\mathrm{C}_{62} \mathrm{H}_{92} \mathrm{~N}_{2} \mathrm{O}_{28}$ 1312.58, observed MW $1313.39(\mathrm{M}+\mathrm{Na})^{+}$.

${ }^{1} \mathrm{H}-\mathrm{NMR}$ spectrum (DMSO- $\mathrm{d}_{6}$ ) of 6 corresponded to the ${ }^{1} \mathrm{H}-\mathrm{NMR}$ spectrum of olivomycin $\mathrm{I},{ }^{13}$ except for the presence of signals at 1.30 p.p.m. $\left(\mathrm{s}, 9 \mathrm{H},-\mathrm{C}\left(\mathrm{CH}_{3}\right)_{3}\right)$ and 4.63 p.p.m. $\left(\mathrm{s}, 2 \mathrm{H},-\mathrm{OCH}_{2}\right)$.

\section{2'-(Carboxymethoxime)-olivomycin I amide of 2-amino-2- methylpropane-1,3-diol (7)}

Compound 7 was obtained in the same manner as $\mathbf{5}$, starting from $2(30 \mathrm{mg}$, $0.024 \mathrm{mmol}), \quad 2$-amino-2-methylpropane-1,3-diol hydrochloride $(10 \mathrm{mg}$, $0.071 \mathrm{mmol}$ ) and PyBOP $(18.4 \mathrm{mg}, 0.071 \mathrm{mmol})$. Yield $10 \mathrm{mg}(30 \%)$. Rf 0.56 (system A), HPLC at Rt 8.11 min, m.p. $141-143^{\circ} \mathrm{C}$ (decomposition). MALDIMS: calculated MW for $\mathrm{C}_{64} \mathrm{H}_{96} \mathrm{~N}_{2} \mathrm{O}_{29}$ 1356.61, observed MW 1379.97 $(\mathrm{M}+\mathrm{Na})^{+}$.

The ${ }^{1} \mathrm{H}$-NMR spectrum (DMSO- $\mathrm{d}_{6}$ ) of 7 corresponded to the ${ }^{1} \mathrm{H}-\mathrm{NMR}$ spectrum of olivomycin $\mathrm{I},{ }^{13}$ except for the presence of signals at 1.30 p.p.m. (s, $\left.3 \mathrm{H},-\mathrm{C}\left(\mathrm{CH}_{2} \mathrm{OH}\right)_{2} \mathrm{CH}_{3}\right), 4.5-4.78$ p.p.m. $\left(4 \mathrm{H},-\mathrm{C}\left(\mathrm{CH}_{2} \mathrm{OH}\right)_{2} \mathrm{CH}_{3}\right)$ and 4.63 p.p.m. (s, $\left.2 \mathrm{H},-\mathrm{OCH}_{2}\right)$.

\section{Cell lines and viability assays}

All antiproliferation assays were performed in 96-well microliter plates (Falcon, Grenoble, France). In all, 5-7.5 $\times 10^{4}$ tumor cells and a given amount of test compound were added to each well. The cells were allowed to proliferate for $48 \mathrm{~h}$ (L1210), or for $72 \mathrm{~h}$ (Molt $4 / \mathrm{C} 8$ or CEM) at $37^{\circ} \mathrm{C}$ in a humidified $\mathrm{CO}_{2}$-controlled atmosphere.

The K562 human leukemia cells were cultured for $72 \mathrm{~h}$ in RPMI- 1640 (PanEco, Moscow, Russia) supplemented with 5\% fetal calf serum (BioWhittaker, Verviers, Belgium), $2 \mathrm{mmol}$ L-glutamine, $100 \mathrm{U} \mathrm{ml}^{-1}$ penicillin, $100 \mu \mathrm{g} \mathrm{ml}^{-1}$ streptomycin at $37^{\circ} \mathrm{C}$ and $5 \% \mathrm{CO}_{2}$ in humidified atmosphere. At the end of the incubation period, the cells were counted in a Coulter Counter (Counter Electronics LTD, Luton, UK). IC $_{50}$ (50\% inhibition concentration) was defined as the concentration of compound that reduced the number of viable cells by $50 \%$. 


\section{Topo-I-poisoning activity}

The reaction mixture $(0.25 \mu \mathrm{g}$ of plasmid pUC19, $1 \mathrm{U}$ of Topo-I and the antibiotics examined) was incubated in buffer $(35 \mathrm{~mm}$ Tris- $\mathrm{HCl}, \mathrm{pH} 8.0$; $0.72 \mathrm{~mm} \mathrm{KCl}, 5 \mathrm{~mm} \mathrm{MgCl}_{2}, 5 \mathrm{~mm}$ dithiothreitol, $5 \mathrm{~mm}$ spermidine, $0.01 \%$ bovine serum albumin) for $30 \mathrm{~min}$ at $37^{\circ} \mathrm{C}$. The reaction was terminated by adding sodium dodecyl sulfate to a final concentration of $1 \%$. After the addition of protease $\mathrm{K}\left(37^{\circ} \mathrm{C}, 40 \mathrm{~min}\right)$, the reaction products were separated in $1 \%$ agarose gel $\left(3 \mathrm{~A} \mathrm{~cm}^{-1}\right)$ for $4-5 \mathrm{~h}$ (buffer composition: $40 \mathrm{~mm}$ Tris base, $1 \mathrm{~mm}$ EDTA and $30 \mathrm{~mm}$ glacial acetic acid). Reaction products were analyzed after staining the gels with an ethidium bromide solution $\left(0.5 \mu \mathrm{g} \mathrm{ml}^{-1}\right)$ and photographed in ultraviolet light.

\section{Antitumor activity}

The antitumor activity of $\mathbf{5}$ was studied in mice bearing lymphocyte leukemia P-388 using both single and multiple i.p. injection regimens. B6D2F1 male mice were injected with $10^{6}$ ascitic cells of lymphoma P-388 cells on day 0 . The sample of 5 was dissolved in $0.1 \%$ DMSO, diluted with physiological solution and injected i.p. on day 3 (single injection regimen), or from day 3 to day 7 (multiple injection regimen).

\section{ACKNOWLEDGEMENTS}

This study was supported by the Russian Fond of Fundamental Research (Grant no. 06-04-08127 for 2006-2007), a grant of the President of Russian Federation for the support of young Russian scientists (AN Tevyashova, MK-5422.2007.4) and the Geconcerteerde Onderzoeksacties (GOA) of the KU Leuven. We thank Mrs Lizette van Berckelaer (Rega Institute, Leuven) for excellent technical assistance, and Dr Marina I Reznikova and Nataly M Malutina (Gause Institute, Moscow) for HPLC analysis.
1 Lombo, F., Menendez, N., Salas, J. A. \& Mendez, C. The aureolic acid family of antitumor compounds: structure, mode of action, biosynthesis, and novel derivatives. Appl. Microbiol. Biotechnol. 73, 1-14 (2006).

2 Chen, K. X., Gresh, N., Hui, X., Pullman, B. \& Zakrzewska, K. Modelling basic features of specificity in DNA-aureolic acid-derived antibiotic interactions. FEBS Lett. 245, 145-149 (1989).

3 Berlin, Y. A. et al. Aureolic acid group of antibiotics. Nature 218, 193-194 (1968).

4 Gause, G. F. Chromomycin, olivomycin, mithramycin. In Handbook of Experimental Pharmacology (eds Sartorelli, A.C. et al.) 615-622 (Springler-Verlag, Berlin, Heidelberg, New York, 1975).

5 Remsing, L. L. et al. Mithramycin SK A novel antitumor drug with improved therapeutic index, mithramycin SA, and demycarosyl-mithramycin SK: three new products generated in the mithramycin producer Streptomyces argillaceus through combinatorial biosynthesis. JACS 125, 5745-5753 (2003).

6 Albertini, V. et al. Novel GC-rich DNA-binding compound produced by a genetically engineered mutant of the mithramycin producer Streptomyces argillaceus exhibits improved transcriptional repressor activity: implications for cancer therapy. Nucleic Acids Res. 34, 1721-1734 (2006).

7 Menendez, N. et al. Deoxysugar transfer during chromomycin $A_{3}$ biosynthesis in Streptomyces griseus subsp. griseus: new derivatives with antitumor activity. Appl. Environ. Microbiol. 72, 167-177 (2006).

8 Remsing, L. L. et al. Ketopremithramycins and ketomithramycins, four new aureolic acid-type compounds obtained upon inactivation of two genes involved in the biosynthesis of the deoxysugar moieties of the antitumor drug mithramycin by Streptomycyes argillaceus, reveal novel insights into post-PSK tailoring steps of the mithramycin biosynthetic pathway. JACS 124, 1601-1614 (2002).

9 Simonova, VS et al. Olivomycin induces tumor cell apoptosis and suppresses p53-induced transcription. Bull. Exp. Biol. Med. 139, 455-459 (2005).

10 Lotito, L., Ferri, F., Russo, A. \& Capranico, G. DNA topoisomerase I as a transcription protein and a lethal cellular toxin. Ital. J. Biochem. 56, 122-129 (2007).

11 Hou, M. N., Lu, W. J., Lin, H. Y. \& Yuann, J. M. Studies of sequence-specific DNA binding DNA cleavage, and topoisomerase I inhibition by the dimeric chromomycin a3 complexed with Fe (II). Biochemistry 47, 5493-5502 (2008).

12 Yoshimura, Y., Koenuma, M., Matsumoto, K., Tori, K. \& Terui, Y. NMR studies of chromomycins, olivomycins and their derivatives. J. Antibiot. 41, 53-67 (1988).

13 Thiem, J. \& Meyer, B. Studies on the structure of olivomycin A and mithramycin by $1 \mathrm{H}$ and 13C nuclear magnetic resonance spectroscopy. Tetrahedron 37, 551-558 (1981). 